\title{
Growth characteristics, economics and hair mineral status of camel calves reared in different systems of management
}

\author{
CHAMPAK BHAKAT ${ }^{1}$, NIRMALA SAINI ${ }^{2}$ and $\mathrm{K}_{\mathrm{M}} \mathrm{L} \mathrm{PATHAK}^{3}$ \\ National Research Centre on Camel, Jorbeer, Bikaner, Rajasthan 334001 India
}

Received: 20 November 2008; Accepted: 23 April 2009

\begin{abstract}
Management systems were compared by conducting 2 trials with different feeding practices. Trials 1 and 2 were conducted by feeding guar phalgati and moth chara as manger feeding, respectively, for 165 days each to 5 camel calves each under intensive system of management (ISM) and semi-intensive system of management (SIM). Total gain in body weight was higher in SIM than ISM group in both the trials. Mean body weight and average growth rate significantly increased in SIM as compared to ISM group at the end of both the trials. The mean moth chara intake was significantly $(\mathrm{P}<0.05)$ more in ISM than SIM. The important hair minerals (calcium, magnesium, copper, zinc, iron and manganese) increased significantly in SIM as compared to ISM group. The manganese status varied significantly $(\mathrm{P}<0.05)$ between groups in moth chara trial. Feeding cost/calf/day and total cost were high in ISM than SIM group in both the trials. Total cost $/ \mathrm{kg}$ body weight gain was quite less and economical in SIM as compared to ISM group. The study indicated SIM better than ISM for economic rearing of camel calf.
\end{abstract}

Key words: Camel, Economics, Farmers, Growth, Hair, Management system, Mineral

Mineral estimation in camel hair is a comparatively newer concept in India. Mineral analysis in hair tissue is an excellent tool for monitoring general health, nutritional status and toxic metal exposure for animals (Manson and Zlothin 1985). Muller (1996) found scalp hair a useful indicator of internal mercury exposure. However, in India, so far camel hair has not been taken up for mineral estimation. The management system should be focused on higher growth performance, proper mineral and good health status, requiring lower economic intervention. Accordingly, present study was conducted with the major objective to investigate influence of management system on growth characteristics, level of important and relevant macro and micro minerals in hair and economical intervention of camel-calf rearing.

\section{MATERIALS AND METHODS}

Experimentation: Management systems were compared by conducting 2 experiments with different feeding practices. The first and second experiments were conducted by feeding guar phalgati (Cyamopsis tetragonoloba) and moth chara (Phaseolus aconitifolius) as manger feeding, respectively for 165 days each. Five camel calves (Camelus dromedarius), 12-15 month-old, belonging to the NRC on Camel, Bikaner, were allotted randomly into each group of management

Present address: ${ }^{1,2}$ Senior Scientist, 3 Director. system. The average initial body weight of 2 groups was more or less similar for both trials. The hetero breed and sex combination were kept in each group of both trials, as per field practice. It contained 2 Bikaneri, 2 Jaisalmeri and 1 Kutchi breed. Each group of both trials contained 3 males and 2 females. The first group was reared under intensive system of management (ISM) and the second group was reared under semi-intensive system of management (SIM) with provision of grazing/browsing daily for about 6 to $7 \mathrm{~h}$ and offered fodder in the evening. The manger feeding was given in both the management systems as per standard feeding schedule followed at the NRCC farm. Daily once watering was done for all camel calves in both groups and in each trial.

Sampling of hair: Camel hair accumulates all important minerals and is commonly available tissue which can easily be collected, stored and transported and if needed can easily be resampled. At the end of each trial hair samples were collected from shoulder, neck, hump and mid region of body of camel calves. The hair were cut with the stainless steel scissors into pieces of about $1 \mathrm{~cm}$ length from each region and mixed well to ensure homogeneity. The skirting of sample was done properly. Samples were washed with acetone and filtered, rinsed with adequate deionized water. These were dried in hot air oven and $0.5 \mathrm{~g}$ of dried mass was taken for further processing. 
Monitoring of growth: The body weight of camel calves were recorded first before shifting them to the respective treatments and thereafter all experimental calves were weighed at fortnightly intervals by using electronic balance. The average weight of 2 consecutive days was taken to represent fortnightly body weight. The weighing was always done in morning before offering feed or water. Body weight formed the basis of determining growth rate of camels. The samples of fodder were collected at fortnightly intervals for estimation of dry matter. The composite samples of fodder were analyzed for proximate principles (AOAC 1995).

Analysis of hair for minerals status: Concentrated nitric acid $(2 \mathrm{ml})$ was added to each hair sample and was kept at $100^{\circ} \mathrm{C}$ until half of the total volume evaporated. The samples were then taken out and cooled. Concentrated perchloric acid ( $2 \mathrm{ml}$ ) was added and again sample were kept until half of the total volume had evaporated. After this procedure, distilled water was added to give a total volume of $10 \mathrm{ml}$ (Brown et al. 1995). The solution was used for determination of important macro- and micro-minerals. Standards for different elements were prepared by diluting stock solution with deionized water as per standard condition for respective elements. The concentration of different elements was determined by atomic absorption spectrophotometer.

Statistical and economic analysis: The experimental data were subjected to statistical analysis. The paired-t test
(Snedecor and Cochran 1989) was applied between 2 management systems for every trial separately. The economic analysis of rearing of camel calves in different systems of management for both trials were carried out by considering the feed cost and the tabular analysis was carried out.

\section{RESULTS AND DISCUSSION}

Growth characteristic: The average body weight at 0 day of trial was almost similar in 2 management groups for both experiments (Table 1). After 165 days of trial period, mean body weight significantly $(\mathrm{P}<0.01)$ increased in SIM as compared to ISM for both trials. The average total gain and growth rate was significantly $(\mathrm{P}<0.01)$ higher in SIM as compared to ISM. The average fodder intake (from manger) per calf per day was on higher side in ISM as compared to SIM group for both trials. The intake of moth chara significantly $(\mathrm{P}<0.05)$ varied between management groups. Bhakat and Nagpaul (2005) had reported that despite similar dry matter content of fodder the intake in all groups were different, which is due to the difference in the types of management (housing) provided to animals.

The analysis of performance data under ISM group for both trials revealed that total dry matter intake (DMI) was $5.41 \pm 0.86 \mathrm{~kg} / \mathrm{calf} /$ day for guar phalgati trial and $6.40 \pm 0.72$ $\mathrm{kg} / \mathrm{calf} /$ day for moth chara trial. The ratio between water intake and DMI was $1.88 \pm 0.64$ for guar phalgati trial and $1.98 \pm 0.51$ for moth chara trial. The feed conversion

Table 1. The growth characteristic of camel calves and economics in different management system with two experiments

\begin{tabular}{|c|c|c|c|}
\hline & & $\begin{array}{l}\text { Intensive system of } \\
\text { management (ISM) }\end{array}$ & $\begin{array}{l}\text { Semi-intensive system } \\
\text { of management (SIM) }\end{array}$ \\
\hline \multicolumn{4}{|l|}{ Experiment with Cyamopsis tetragonoloba } \\
\hline Mean body weight after 165 days & $\mathrm{kg}$ & $272.35^{* *} \pm 12.34$ & $285.48^{* *} \pm 8.66$ \\
\hline Mean body weight at 0 day & $\mathrm{kg}$ & $223.88^{\mathrm{NS}} \pm 11.76$ & $228.79^{\mathrm{NS}} \pm 12.14$ \\
\hline Total gain in body weight & $\mathrm{kg}$ & 48.47 & 56.69 \\
\hline Average daily gain & g/day & $278.46^{* *} \pm 49.83$ & $325.16^{* *} \pm 47.18$ \\
\hline Mean guar phalgati intake (manger) & $\mathrm{kg} / \mathrm{calf} /$ day & $6.022^{\mathrm{NS}_{ \pm 0}} .85$ & $5.14^{\mathrm{NS}_{ \pm 0.73}}$ \\
\hline Mean water intake (trough) & $\mathrm{kg} / \mathrm{calf} /$ day & $10.20^{\mathrm{NS}_{ \pm} 1.70}$ & $10.01^{\mathrm{NS}_{ \pm}} .62$ \\
\hline \multicolumn{4}{|l|}{ Economic analysis } \\
\hline Total feeding cost for 165 days & Rs/calf & 2085.93 & 1781.01 \\
\hline Daily feeding cost per calf & Rs & 12.64 & 10.79 \\
\hline Overall total cost for $1 \mathrm{~kg}$ gain & Rs & 43.04 & 31.42 \\
\hline \multicolumn{4}{|l|}{ Experiment with Phaseolus aconitifolius } \\
\hline Average body weight after 165 days & $\mathrm{kg}$ & $313.60^{* *} \pm 11.24$ & $348.35^{* *} \pm 8.12$ \\
\hline Average body weight at 0 day & $\mathrm{kg}$ & $255.78^{\mathrm{NS}} \pm 10.26$ & $262.50^{\mathrm{NS}_{ \pm}}+11.34$ \\
\hline Total gain in body weight & $\mathrm{kg}$ & 57.82 & 85.85 \\
\hline Average daily gain & g/day & $330.76^{* *} \pm 43.57$ & $475.81^{* *} \pm 39.33$ \\
\hline Average intake of moth chara (manger) & $\mathrm{kg} / \mathrm{calf} /$ day & $7.91 * 0.48$ & $6.24^{*} \pm 0.29$ \\
\hline Average intake of water (trough) & $\mathrm{kg} / \mathrm{calf} /$ day & $12.77^{\mathrm{NS}} \pm 1.24$ & $12.16^{\mathrm{NS}_{ \pm} 1.55}$ \\
\hline \multicolumn{4}{|l|}{ Economic analysis } \\
\hline Total feeding cost for 165 days & Rs/calf & $2,698.25$ & $2,368.08$ \\
\hline Total feeding cost & Rs/day/calf & 16.35 & 14.35 \\
\hline Overall total cost for $1 \mathrm{~kg}$ gain & Rs & 46.66 & 27.58 \\
\hline
\end{tabular}

**Significant at $1 \%, *$ significant at $5 \%$, NS: Nonsignificant. 
Table 2. Average $\pm \mathrm{SE}$ of mineral status $(\mathrm{mg} / \mathrm{g})$ in hair of camel calve's reared under different management system with two experiments

\begin{tabular}{|c|c|c|c|c|c|c|}
\hline & \multicolumn{3}{|c|}{ Macro-mineral } & \multicolumn{3}{|c|}{ Micro-mineral } \\
\hline & Calcium & Magnesium & Copper & Zinc & Iron & Manganese \\
\hline \multicolumn{7}{|l|}{ Experiment with Cyamopsis tetragonoloba } \\
\hline Intensive management (ISM) & $434.40^{*} \pm 60.21$ & $67.60 * 66.33$ & $4.30 * \pm 0.44$ & $57.56^{*} \pm 2.33$ & $216.08^{*} \pm 30.89$ & $20.60^{\mathrm{NS}} \pm 1.02$ \\
\hline Semi-intensive management (SIM) & $549.60 * \pm 74.45$ & $88.92 * \pm 2.41$ & $6.16^{*} \pm 0.72$ & $66.04 * \pm 4.38$ & $285.72 * \pm 26.55$ & $21.56^{\mathrm{NS}_{ \pm}} .65$ \\
\hline \multicolumn{7}{|l|}{ Experiment with Phaseolus aconitifolius } \\
\hline Intensive system management (ISM) & $476.00^{*} \pm 127.98$ & $69.84 * \pm 3.18$ & $5.72^{*} \pm 0.99$ & $54.76^{*} \pm 1.46$ & $261.92^{*} \pm 33.37$ & $32.92 * \pm 4.36$ \\
\hline Semi-intensive management (SIM) & $719.72^{*} \pm 78.62$ & $77.48^{*} \pm 3.67$ & $7.36 * 0.66$ & $64.25^{*} \pm 2.04$ & $319.36^{*} \pm 27.91$ & $45.80^{*} \pm 1.83$ \\
\hline
\end{tabular}

*Significant at $5 \%$, NS, nonsignificant.

efficiency was $10.89 \pm 0.56$ for guar phalgati trial and $11.92 \pm 0.78$ for moth chara trial. The total DMI per $100 \mathrm{~kg}$ body weight was $2.20 \pm 0.32 \mathrm{~kg} /$ calf for guar phalgati trial and $2.24 \pm 0.21 \mathrm{~kg} /$ calf for moth chara trial. Total intake per day per $\mathrm{kg}$ metabolic body size was $0.088 \pm 0.008 \mathrm{~kg}$ for guar phalgati trial and $0.086 \pm 0.007 \mathrm{~kg}$ for moth chara trial. The average water intake (from trough) was more in ISM as compared to SIM group for both trials. The relationship between dry matter intake and growth of weaned calves seems positively correlated Singh et al. (2000). Tandon et al. (1993) found that dry fodder intake and water intake were positively correlated. Sahani et al. (1992) observed that the average daily gains in 2 months old Bikaneri and Jaisalmeri calves were 553.3 and $546.6 \mathrm{~g}$, respectively. The present data are consistent with the earlier reports. Khanna et al. (1990) reported that significant correlation coefficients existed between body weight and measurement in Bikaneri, Jaisalmeri, Kutchi and Mewari breed of camels.

Hair macro mineral status: Calcium and magnesium were significantly $(\mathrm{P}<0.05)$ increased in SIM as compared to ISM group in both experiments (Table 2). The level of calcium varied between 286 and $604 \mathrm{mg} / \mathrm{g}$ in ISM whereas in SIM it varied between 330 and $720 \mathrm{mg} / \mathrm{g}$ in case of guar phalgati trial. The level of magnesium varied between 42.4 and 76 $\mathrm{mg} / \mathrm{g}$ in ISM whereas in SIM it varied between 81.8 and 94 $\mathrm{mg} / \mathrm{g}$ in guar phalgati trial. But in moth chara trial, magnesium ranged between 57.8 and $75 \mathrm{mg} / \mathrm{g}$ in ISM whereas in SIM it varied between 68.6 and $86.8 \mathrm{mg} / \mathrm{g}$. Kayar et al. (2004) reported that levels of some elements were affected to a higher or lower degree by nutritional differences in horse.

Hair micro mineral status: The important micro-mineral like copper, zinc, iron and manganese were higher in SIM as compared to ISM group in both the experiments. The level of copper, zinc, iron significantly $(\mathrm{P}<0.05)$ varied between management systems in each trial. The copper ranged between 4 and $9.6 \mathrm{mg} / \mathrm{g}$ in ISM whereas in SIM it varied between 5.8 to $9.4 \mathrm{mg} / \mathrm{g}$ in moth chara trial. The level of zinc varied between 49.4 and $62.6 \mathrm{mg} / \mathrm{g}$ in ISM whereas in SIM it varied between 53.2 and $77.2 \mathrm{mg} / \mathrm{g}$ in guar phalgati trial. But in moth chara trial, the zinc ranged between 49.6 and $58.6 \mathrm{mg} / \mathrm{g}$ in ISM whereas in SIM it varied between 59 and $71.24 \mathrm{mg} / \mathrm{g}$. The level of iron widely varied i.e 140.6 and $318 \mathrm{mg} / \mathrm{g}$ and 235.8 and $366 \mathrm{mg} / \mathrm{g}$ in ISM, SIM respectively, in guar phalgati trial. Similarly, the iron status ranged between 165.6 and $374 \mathrm{mg} / \mathrm{g}$ in ISM whereas in SIM it varied between 226 and $384.8 \mathrm{mg} / \mathrm{g}$ in moth chara trial. The manganese status varied significantly $(\mathrm{P}<0.05)$ between management system in moth chara trial but non-significant variation was found in guar phalgati trial. In case of moth chara trial, the manganese status ranged between 19.4 and $46 \mathrm{mg} / \mathrm{g}$ and 43 and $52.8 \mathrm{mg} / \mathrm{g}$ in ISM and SIM, respectively. Chatterjee et al. (2005) found almost similar manganese status in yak hair.

Economic analysis: Almost all kinds of costs for camel calves rearing were more or less similar except feeding cost. The total feeding cost (Rs) per calf for 165 days was more in ISM group as compared to SIM group for both trials (Table 1). The total feeding cost per day per calf was high in ISM than SIM group in both trials. Total cost per kg body weight gain was quite less in SIM as compared to ISM. Since total body weight gain and average growth rate were quite high, in SIM, so it was more economical than ISM. Pathak et al. (2007) reported that the health of individual/herd of camels has its role from the economic point of view as well as from public health consideration. Camel hair is being formed and exposed to internal metabolic environment including blood, lymph and extra cellular fluids. Constituents entering into body are then accumulated in hair and reflect a time weighed exposure record of nutritional and toxic metal intake. The minerals concentration in camel hair can very well be used as an indicator of trend of mineral deficiency/toxicity in soil. The levels of mineral in camel hair can be used in the diagnosis of various diseases and metabolic disorders and determination of nutritional status. The study indicated that as far as present management practices are concerned semi-intensive system of management is better over the intensive system of management for economic rearing of camel-calf.

\section{ACKNOWLEDGEMENT}

Authors are thankful to the ICAR for funding the work under Livestock Production and Management project. The 
authors are equally indebted to all persons who directly or indirectly cooperated in the execution of the research work.

\section{REFERENCES}

AOAC. 1995. Animal Feeds. Official Methods of Analysis of AOAC International. 16th edn. AOAC International, Virginia, USA. Vol. I. 1-18.

Bhakat C and Nagpaul P K. 2005. Effect of housing systems on the growth performance of crossbred goats. Indian Journal of Animal Sciences 75 (1): 69-73.

Brown A A and Taylor A. 1995. Applications of a slotted quartz tube and flame atomic absorption spectrophotometer to the analysis of biological samples. Journal of Analytic Atomic Spectrometry 110: 579-82.

Chatterjee A, Raquib M, Sheikh I U and Bhattacharya M. 2005. Elemental status in yak hair. Indian Veterinary Journal 82: 52628.

Kayar ME, Maden A, Gulyasar D, Tosun R and Dourka C. 2004. Determination of trace elements $(\mathrm{Fe}, \mathrm{Cu}$ and $\mathrm{Zn})$ in serum and tail hair of healthy horses as a function of nutritional differences in certain months. Nigerian Veterinary Journal 25(1): 9-13.

Khanna N D, Rai A K and Tandon S N. 1990. Breeding parameters of Indian camels. Indian Journal of Animal Sciences 60 (11): 1347-54.

Manson, P. and Zlotkin, S. 1985. Hair analysis-a critical review. Journal of Condition Medical Association 133: 186-88.

Muller, W. 1996. Biological monitoring of mercury vapour exposure by scalp hair analysis in comparison to blood and urine. Toxicology Letters 88: 1-3.

Pathak K M L, Ghorui S K and Sena S. 2007. Camel disease diagnostics: present and future scenario. ASCAD Symposium on Strengthening of Disease Diagnostic Facilities for Sustainable Livestock and Poultry Development. Udaipur, India 10-11 March, 2007 pp 50-55.

Sahani M S, Khanna N D and Tandon S N. 1992. Studies on quantitative and qualitative genetic parameters in Indian camels. Annual Report. NRCC, Bikaner, pp. 31-42.

Singh G P, Nagpal A K, Saini N and Jayant P. 2000. Studies on feed requirement and feed resources evaluation for optimum production. Annual Report, NRCC, Bikaner, pp. 26-34.

Snedecor W G and Cochran G W. 1989. Statistical Methods Ltd New Delhi, India. Oxford and IBH publishing Co. Pvt. Ltd. New Delhi, India.

Tandon S N, Khanna N D and Sharma N. 1993. To develop suitable management practices for rearing camels. Annual Report, NRCC, Bikaner, pp. 45-49. 